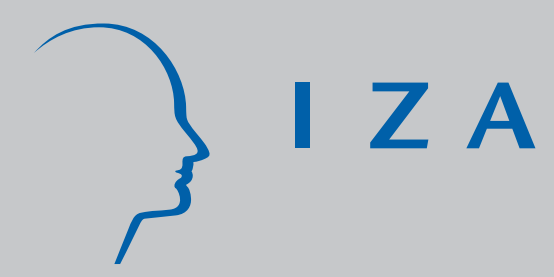

IZA DP No. 903

Evaluating the Causal Effects

of Foreign Acquisition on Domestic Skilled and Unskilled Wages

Sourafel Girma

Holger Görg

October 2003 


\title{
Evaluating the Causal Effects of Foreign Acquisition on Domestic Skilled and Unskilled Wages
}

\author{
Sourafel Girma \\ University of Leicester \\ Holger Görg \\ University of Nottingham, DIW Berlin \\ and IZA Bonn \\ Discussion Paper No. 903 \\ October 2003
}

\author{
IZA \\ P.O. Box 7240 \\ D-53072 Bonn \\ Germany \\ Tel.: +49-228-3894-0 \\ Fax: +49-228-3894-210 \\ Email: iza@iza.org
}

\begin{abstract}
This Discussion Paper is issued within the framework of IZA's research area Internationalization of Labor Markets. Any opinions expressed here are those of the author(s) and not those of the institute. Research disseminated by IZA may include views on policy, but the institute itself takes no institutional policy positions.
\end{abstract}

The Institute for the Study of Labor (IZA) in Bonn is a local and virtual international research center and a place of communication between science, politics and business. IZA is an independent, nonprofit limited liability company (Gesellschaft mit beschränkter Haftung) supported by Deutsche Post World Net. The center is associated with the University of Bonn and offers a stimulating research environment through its research networks, research support, and visitors and doctoral programs. IZA engages in (i) original and internationally competitive research in all fields of labor economics, (ii) development of policy concepts, and (iii) dissemination of research results and concepts to the interested public. The current research program deals with (1) mobility and flexibility of labor, (2) internationalization of labor markets, (3) welfare state and labor market, (4) labor markets in transition countries, (5) the future of labor, (6) evaluation of labor market policies and projects and (7) general labor economics.

IZA Discussion Papers often represent preliminary work and are circulated to encourage discussion. Citation of such a paper should account for its provisional character. A revised version may be available on the IZA website (www.iza.org) or directly from the author. 
IZA Discussion Paper No. 903

October 2003

\section{ABSTRACT \\ Evaluating the Causal Effects of Foreign Acquisition on Domestic Skilled and Unskilled Wages*}

This paper investigates the effects of the takeover of a domestic establishment by foreign owners on the domestic target's development of wages for skilled and unskilled workers. We pay particular attention to identifying the causal effect, using a propensity score matching approach combined with a difference-in-differences estimator, and differences in post acquisition effects depending on the nationality of the acquirer. Our results suggest that there is substantial heterogeneity in the post-acquisition wage effect depending on the nationality of the foreign acquirer, the industry in which the firms operate and the skill group of workers. In particular, we find that skilled workers, on average, experience a post acquisition increase in the wage rate following an acquisition by a US firm, while no such effect is discernible following acquisitions by EU or firms of other nationalities. For unskilled workers, there are positive post acquisition wage effects from take-overs by EU firms in the electronics industry and US firms in the food industry.

JEL Classification: F23, J31

Keywords: multinationals, acquisitions, wages, matching estimator

Corresponding author:

Sourafel Girma

Department of Economics

University of Leicester

Leicester LE1 7RH

United Kingdom

Email: sg116@le.ac.uk

\footnotetext{
* This work contains statistical data from ONS which is Crown copyright and reproduced with the permission of the controller of HMSO and Queen's Printer for Scotland. The use of the ONS statistical data in this work does not imply the endorsement of the ONS in relation to the interpretation or analysis of the statistical data. Holger Görg gratefully acknowledges financial support through the Leverhulme Trust Programme Grant F114/BF.
} 


\section{Introduction}

It is by now accepted as a stylised fact that foreign multinational enterprises (MNEs) perform better than domestic firms for a number of performance indicators. Recent analyses of micro level data commonly find that MNEs pay higher wages than their domestic counterparts; see, for example, the evidence by Feliciano and Lipsey (1999) for the US, Girma, Greenaway and Wakelin (2001) for the UK, Lipsey and Sjöholm (2001) for Indonesia and Görg, Strobl and Walsh (2003) for Ghana.

These observations are, of course, not new in the literature on the economics of MNEs. As far back as Dunning and Morgan (1980) the authors found that US multinationals paid higher wages than UK manufacturing firms. What is new, however, is that more recent studies can control for many firm characteristics that may potentially be different between foreign multinationals and domestic firms and which may potentially impact on wage differences. Obvious candidates are sector and size differences between domestic and foreign firms, the latter generally being larger and operating in more high tech industries than the former. This, of course, can explain some of the wage and productivity differentials between these groups of firms. However, controlling for size of the firm and including sectoral dummies, Girma et al. (2001), for example, still find that foreign firms pay on average about 5 percent higher wages than domestic firms.

While such studies go a long way towards identifying the performance difference that is attributable to multinationality per se, a fundamental problem arguably remains. As Tybout (2000), for example, points out, multinationals may be attracted to more technology intensive industries, which also are more productive and pay higher wages. Hence, there would be an endogeneity problem in the regressions and the productivity and wage differential between foreign and domestic firms would be difficult to interpret. As pointed out, the inclusion of some industry and firm characteristics might go some way 
towards reducing this bias, though the inclusion of all possible relevant control variables is a difficult if not impossible task.

In this paper we try to overcome this problem by analysing the effects of an acquisition of a domestic establishment by a foreign multinational enterprise on wages for skilled and unskilled workers using establishment level data for the UK. Assuming that an acquisition does not change any of the main characteristics of the takeover target (at least in the short run) a possible effect of the foreign acquisition on wages in the domestic target can be attributed to the change in ownership from domestic to foreign. We attempt to identify the causal effect of a foreign acquisition on wages using a propensity score matching approach combined with a difference-in-differences estimator (see Blundell and Costa Dias, 2000).

Conyon, Girma, Thompson and Wright (2002) present an earlier study of the effect of foreign acquisitions on wages in the domestic target. They use data for the UK and their study is, hence, most relevant to our work. Based on company level data for manufacturing industries they find that foreign acquired firms pay 3.4 percent higher wages than non-acquired firms, controlling for firm size as well as fixed firm and industry specific effects. However, this differential disappears when labour productivity is added as a regressor, indicating that the wage difference can be wholly attributed to productivity differences between foreign and domestic firms. ${ }^{1}$

We extend the existing literature in a number of ways. First, Conyon et al. (2002) use a company level data set where acquisitions can only be identified indirectly if a firm changes from being independent to being a subsidiary. Our data set is at the establishment (mostly plant) level and allows us to identify takeovers more directly. Second, we use a

\footnotetext{
${ }^{1}$ Lipsey and Sjöholm (2002) undertake a related study using firm level data for Indonesia and find significant positive effects of foreign acquisitions on wages, even when controlling for firm and industry characteristics. However, it should be noted that, in contrast to Conyon et al (2002), they do not control for productivity in the estimations.
} 
matching and difference-in-differences approach to identify the causal effect of the takeover on wages, improving on the existing literature. Thirdly, while Conyon et al. (2002) look at average wages per firm, our data set allows us to distinguish the effect of an acquisition on wages for skilled and unskilled workers separately. Fourthly, we allow for different effects of acquisitions by firms from different home countries, in particular from the US and EU countries. As we discuss below, these distinctions bring up interesting differences in results for the two groups of workers and different firm nationalities.

Before proceeding with the analysis we need to discuss briefly why we would expect an effect of a foreign acquisition on wages. The traditional theory of multinationals postulates that they have access to some form of firm specific asset (FSA), such as a superior production technique, know-how, or management strategy, which has at least some of the characteristics of a public good and enables the firm to locate profitably abroad (Caves, 1996; Markusen, 1995). This FSA implies that multinationals operate at a "superior" level of technology and, hence, explains why they are usually expected to have higher levels of productivity compared to purely domestic firms. As long as labour markets are at least to some degree competitive, higher levels of productivity will imply higher wages, hence explaining a wage positive differential. The empirical finding by Conyon et al. (2002) is very much in line with this theoretical hypothesis - MNEs pay higher wages because they are more productive.

Is there any reason to expect any additional effects of foreign ownership on wages? Carmichael (1992), for example, argues that US multinationals in the UK paid higher wages than domestic firms in order to "bribe" workers to avoid industrial relations disputes. However, Conyon et al. (2002) point out that multinationals, in particular from Japan, may actually bring with them successful work practices, industrial relations arrangements etc. which will be implemented in their foreign subsidiaries. Again, the 
implementation of arrangements for "peaceful" industrial relations may be exchanged for higher wages to compensate workers.

In the empirical analysis below we do find that foreign acquisitions lead to changes in domestic wages for skilled and unskilled workers, although there is substantial heterogeneity in the magnitude of the effect depending on skill group of workers, industry of the establishment and nationality of the acquirer.

The remainder of the paper is structured as follows. In Section 2 we briefly outline the empirical methodology used in order to establish the causal effect of foreign acquisitions on wages. Section 3 describes the data set. Section 4 presents the results and implication of the matching process, used in order to establish a valid counterfactual for the subsequent econometric analysis of the effect of foreign acquisition on wage rates, which is reported in Section 5. Section 6 summarises the main results and concludes.

\section{Empirical methodology}

The aim of the paper is to analyse whether there is a causal effect from an acquisition of a domestic establishment by a foreign owner on wages in the domestic target. In other words, the empirical modelling problem is the evaluation of the causal effect of foreign acquisition on $y$, where $y$ represents skilled or unskilled wages in the target establishment. Let $A C Q_{i t} \in\{0,1\}$ be an indicator of whether establishment $i$ is acquired by a foreign MNE at time period $t$, and let $y_{i t+s}^{1}$ be wage at time $t+s, s \geq 0$, following acquisition. Also denote $y_{i t+s}^{0}$ as the wage of the plant had it not been acquired. The causal effect of foreign ownership for firm $i$ at time period $t+s$ is then defined as:

$$
y_{i t+s}^{1}-y_{i t+s}^{0}
$$


The fundamental problem of causal inference is that the quantity $y_{i t+s}^{0}$ is unobservable. Thus the analysis can be viewed as confronting a missing-data problem. Following the microeconometric evaluation literature (e.g. Heckman et al, 1997), we define the average effect of acquisition on the acquired firms as

$$
E\left\{y_{t+s}^{1}-y_{t+s}^{0} \mid A C Q_{i t}=1\right\}=E\left\{y_{t+s}^{1} \mid A C Q_{i t}=1\right\}-E\left\{y_{t+s}^{0} \mid A C Q_{i t}=1\right\}
$$

Causal inference relies on the construction of the counterfactual for the last term in equation (2), which is the outcome the acquired establishments would have experienced, on average, had they not been acquired. This is estimated by the average wage of the plants that remained in domestic hands, $E\left\{y_{i t+s}^{0} \mid A C Q_{i t}=0\right\}$.

This is, of course, only a valid approximation if there are no contemporaneous effects that are correlated with $A C Q$ and that are not controlled for. If that is not the case then the empirical analysis is plagued with endogeneity and simultaneity bias. Hence, an important feature in the accurate construction of the counterfactual is the selection of a valid control group. The approach we take is to employ matching techniques. The purpose of matching is to pair each foreign acquired plant with a domestic establishment that has not undergone any ownership change on the basis of some observable variables, in such a way that the domestic establishments' wage dynamics can be studied to generate the counterfactual for the newly foreign owned plants.

Since matching involves comparing acquired and non-acquired establishments across a number of observable pre-acquisition characteristics (e.g., productivity, size, industry characteristics), it is desirable to perform the matching on the basis of a single index that captures all the information from those variables. We adopt the method of propensity score-matching due to Rosenbaum and Rubin (1983), which suggests the use of the probability of receiving treatment (foreign acquisition in the present context) conditional on those characteristics, to reduce the dimensionality problem. 
Accordingly, we first identify the probability (or propensity score) of being acquired using a probit model

$$
P\left(A C Q_{i t}=1\right)=F\left(X_{i}, Z_{j}\right)
$$

which includes establishment $\left(X_{i}\right)$ and industry $\left(Z_{j}\right)$ characteristics. ${ }^{2}$ Then let $P_{i t}$ denote the predicted probability of being acquired at time $t$ for plant $i$ (which is actually taken over). A non-acquired $j$, which is 'closest' in terms of its 'propensity score' to an acquired plant is then selected as a match for the latter using the 'caliper' matching method. ${ }^{3}$ More formally, at each point in time and for each newly acquired plant $i$, a domestic firm $j$ is selected such that ${ }^{4}$

$$
\lambda>\left|P_{i t}-P_{j t}\right|=\min _{k \in\{\text { unacuried }\}}\left\{\left|P_{i}-P_{j}\right|\right\}
$$

where $\lambda$ is a pre-specified scalar. This type of matching procedure is preferable to randomly or indiscriminately choosing the comparison group, because it is less likely to induce estimation bias by picking firms with markedly different characteristics.

Having constructed the comparison group (C) of firms that are similar to the acquired firms (A), a standard matching estimator of the causal effect of foreign acquisition can be written as

$$
\delta=\sum_{i \in A}\left(y_{i}-\sum_{j \in C} m_{i j} y_{i}\right)
$$

where the $m_{i j}$ are the weights placed on the comparison firm $j$, which are generated by the matching algorithm. Instead of using this estimator we employ the more general

\footnotetext{
${ }^{2}$ The choice of covariates is influenced by the acquisition literature (e.g. Conyon et al, 2002, Girma and Görg, 2002, Harris and Robinson, 2002).

${ }^{3}$ The matching is performed in Stata Version 7 using the software provided by Sianesi (2001).

4 A non-acquired plant can be matched to more than one acquired establishment. Similarly, it can happen that an acquired plant may not have a match.
} 
difference-in-differences estimator on the matched firms to isolate the effects of foreign acquisition on skilled and unskilled wages of erstwhile domestic plants. ${ }^{5}$

The version of the combined matching and difference-in-differences estimator we use can be described as follows. Firstly, the difference between the average wage before and after the change of ownership, say $\Delta^{a} y$, is calculated. Then this difference is further differenced with respect to the before and after difference for the comparison control group, say $\Delta y^{c}$, to obtain the difference-in-differences estimator $\delta=\Delta^{a} y-\Delta^{c} y$.

It follows that, defining $A C Q$ and $P A C Q$ dummy variables for the acquisition year and the post-acquisition period respectively, the $\delta$ s in the regression

$$
y_{i t}=\phi+\delta_{1} A C Q+\delta_{2} P A C Q_{i t}+u_{i t}
$$

can be interpreted as the average change in $y$ that can be attributed to foreign acquisition. In order to control for possible observable factors that may be correlated with changes in wages, we extend the basic framework in (6) by including a vector of regressors including establishment and industry characteristics.

\section{Description of the data}

We use data from the Annual Respondents Database (ARD), which is provided by the Office for National Statistics (ONS) in the UK under controlled conditions. The dataset consists of individual establishments' records underlying the Annual Census of Production and the data used cover the period 1980 to 1994. As Barnes and Martin (2002)

\footnotetext{
5 This is motivated by recent studies which argue that standard matching estimators are usually unsatisfactory, but in combination with difference-in-differences methodology can have the potential to “...improve the quality of non-experimental evaluation results significantly" (Blundell and Costa Dias, 2000, p. 438).
} 
provides a useful introduction to the data set, we only include a brief discussion of some of its features relevant to the present work.

In the period covered by our data, the ARD consists of two files. What is known as the 'selected file', contains detailed information on a sample of establishments that are sent inquiry forms. The second file comprises the 'non-selected' (non-sampled) establishments and only basic information such as employment, location, industry grouping and foreign ownership status is recorded. During our study period, some 14,000-19,000 establishments are selected each year, based on a stratified sampling scheme. The scheme tends to vary from year to year, but over the period under consideration establishments with more than 100 employees were always sampled.

In the data, an establishment is defined as the smallest unit that is deemed capable of providing information on the Census questionnaire. Thus a 'parent' establishment reports for more than one plant (or 'local unit' in the parlance of ARD). For selected multi-plant establishments, we only have aggregate values for the constituent plants. Indicative information on the 'children' is available in the 'non-selected' file. In the sample period considered in this paper over 95 percent of the establishment in both the electronics and food industries are single-plant firms. In the actual sample we used for the econometric estimation this figure is around 80 percent for both sectors. Thus most of the data we used is actually plant level data. As a result we tend to use the terms plant and establishment interchangeably.

In this paper we focus on two broad industries, namely electronics and food. ${ }^{6} \mathrm{We}$ have two reasons for doing so. First, foreign-owned firms are important players in both sectors, accounting for about 19 percent of employment in electronics and 10 percent of employment in the food industry in 1996 (see Griffith and Simpson, 2003, Table 4). 
Second, we may expect the two sectors to be different in their technology usage and, hence, there may be differences in the determinants of foreign acquisition and its effects on skilled and unskilled wages.

In the ARD a consistently defined nationality indicator identifies whether an establishment is domestic or foreign owned, and foreign acquisition is said to have occurred in year $t$ when an establishment that has been in domestic hands up to year $t-1$ becomes a subsidiary of a foreign-based multinational. Since the matching process described in the previous section requires data on the pre-acquisition period, we consider foreign take-overs that took place between 1981 and 1994. Overall, there were 228 and 108 acquisitions in the electronics and food industries over that period, respectively.

\section{Matching process}

As pointed out above, the aim of the matching procedure is to find an adequate control group against which we can compare the evolution of wages in acquired establishments. To do the matching we estimate a probit of the following form:

$$
\begin{aligned}
& P\left(A C Q_{i t}=1\right)=F\left(\text { wage }_{i t-1} \text {, size }_{i t-1}, \text { size squared }_{t-1} \text {, age }_{i t-1} \text {, age squared }_{i t-1}\right. \\
& \text { productivty growth }_{i t-1}, \text { assisted area dummy, industry dummies) }
\end{aligned}
$$

where the choice of covariates is influenced by the empirical literature on foreign acquisitions (e.g. Conyon et al, 2002, Girma and Görg, 2002, Harris and Robinson, 2002). Such studies usually argue that establishment size and age are important determinants for acquisitions and hence we include those in the probit, allowing for a non-linear relationship. Also, high productivity plants are commonly found to be more likely to be taken over, indicating that foreign firms may be "cherry picking" the best performing establishments. We include a productivity growth variable that allows for non-constant

\footnotetext{
${ }^{6}$ More precisely, using SIC 1980 classification, SIC 33 (manufacture of office machinery and data processing equipment), SIC 34 (electrical and electronic engineering), and SIC 41/42 (food, drink and
} 
returns to scale as in Girma and Görg (2002). In order to address the argument that foreign firms may take over high or low wage establishments (see Lipsey and Sjöholm, 2002) wages by skill groups prior to acquisition are also included in the probit. Finally, to control for sectoral and regional effects we include a full set of industry dummies as well as a dummy indicating whether or not a plant is located in an assisted area in the UK.

Estimating this probit using the data for the electronics and food industries yields the results reported in Table 1. Results are largely as expected, though there are some differences, in particular in terms of statistical significance of the estimates, between foreign acquisitions in the two industries.

\section{[Table 1 here]}

The population of the potential comparison group consists of domestic plants that are not acquired by foreign multinationals. As can be seen in Table 2 some of these plants were found to be good matches for the foreign acquired firms. ${ }^{7}$ Roughly about one in 5 domestic firms are deemed to display observable characteristics similar to those acquired companies in the electronics industry, the comparable figure for the food industry is one in 10. The success of the propensity score-matching is confirmed in Table 3 , where it can be seen that matched firms display considerable homogeneity as opposed to the stark contrast we observe in the unmatched samples.

\section{[Tables 2 and 3 here]}

\section{Difference-in-differences estimation}

The next step in the analysis is to estimate variants of equation (6) on the matched sample in order to examine the causal effect of foreign acquisition on wages for skilled

\footnotetext{
tobacco).

${ }^{7}$ Notice the propensity score-matching method can pair a comparison firm with more than one acquired firms. It is also possible that an acquired firm may not have a good enough matching firms.
} 
and unskilled workers in the acquired establishment. As is common in the literature (e.g., Machin and Van Reenen, 1998), we define skilled and unskilled workers in terms of nonproduction and production workers, respectively.

In order to control for possible observable factors that may be correlated with changes in wages we extend equation (6) by including a number of establishment and industry specific variables, as well as time dummies to control for overall economy wide shocks. Specifically, we estimate the following two equations which represent reduced form wage equations for skilled and unskilled wages,

$$
\begin{aligned}
& \ln W_{i t}^{s}=\beta_{0}+\beta_{1} \ln W_{i t}^{u}+\beta_{2} \ln O U T W_{i t}^{s}+\beta_{3} \ln K_{i t}+\beta_{4} A C Q_{i t}+\beta_{5} P A C Q_{i t}+D_{t}+\varepsilon_{i t} \\
& \ln W_{i t}^{u}=\gamma_{0}+\gamma_{1} \ln W_{i t}^{s}+\gamma_{2} \ln O U T W_{i t}^{u}+\gamma_{3} \ln K_{i t}+\gamma_{4} A C Q_{i t}+\gamma_{5} P A C Q_{i t}+D_{t}+u_{i t}
\end{aligned}
$$

where $i$ and $t$ index plant and time periods respectively, $W$ is plant level wages where the superscripts $s$ and $u$ are used to denoted skilled and unskilled wages respectively. The average regional and sectoral wage rates are denoted by $O U T W, K$ represents plant size (measured in terms of capital stock), $D$ denotes a full set of time dummies, and $\varepsilon$ and $u$ are the usual white noise disturbance terms. The main variables of interest are the contemporaneous foreign acquisition indicator $(A C Q)$ and the lagged post-acquisition dummy $(P A C Q)$.

The variables included in this empirical model of wage determination are fairly standard in the literature. The cross wage term is included to capture the interaction of wage rates on the labour market and to investigate whether wage rates for different types of workers move in the same or opposite directions. The industry-region wage rate is included to capture outside wage effects, i.e., supply factors, via alternative wage rates available on the labour market (see Driffield and Girma, 2003). ${ }^{8} \quad$ In fact, Nickell and Wadhwani (1990) show that wages paid outside the firm/plant have great influence on the

\footnotetext{
${ }^{8}$ Note that we are thus assuming that the labour market is regional and industry specific.
} 
wage determination process in the UK. The model also includes plant size since a positive employer size-wage relationship is well documented in the empirical literature, and various theories are offered to explain this phenomenon (e.g. Brown and Medoff, 1989) . Finally, we also control for economy-wide shocks affecting the dynamics of wages with a full set of time dummies $\left(D_{t}\right)$.

The inclusion of the cross wage terms implies that we have a system of two simultaneous equations. We estimate the system using the iterative three stage least squares estimation technique, ${ }^{9}$ the results of which are reported in Table 4 . We report estimations for the matched sample as well as for the whole sample in order to contrast the result and make apparent the possible bias we would experience if we were to rely on the estimations from the whole sample only. In terms of the control variables, we find that the outside wage and plant size exert positive impacts on plants' wage rates, as would be expected. The coefficient on the cross-wage terms are mostly negative in the unskilled wage equation and mostly statistically insignificant in the skilled wage equation, indicating that the latter is not strongly affected by the wage for unskilled workers.

For the purpose of this paper we are mainly interested in the effect of foreign acquisitions on wages, which are captured by the contemporaneous acquisition dummy and the dummy for the post acquisition period. Here we find an interesting difference between the estimations for the whole sample and the matched sample. For the former, the coefficients are in all cases positive and statistically significant, while in the latter we only find a statistically significant impact in the post acquisition period in the electronics industry. This illustrates the potential problem that the estimation on the full sample suffers from endogeneity and simultaneity bias which leads to an overstatement of the causal effect of foreign acquisition on wages. Taking the point estimates at face value, our

\footnotetext{
${ }^{9}$ The iterative procedure produces estimates asymptotically equivalent to maximum likelihood estimates.
} 
regression results for the matched sample in the electronics industry indicate that a foreign acquisition raises wages of skilled and unskilled workers by 2.4 and 4.0 percent respectively in the post acquisition period. No such post acquisition effect is discernable for plants in the food industry.

\section{[Table 4 here]}

An interesting question to ask is whether takeovers by multinationals from different home countries have different effects on post-acquisition wages. We may expect this for at least two reasons. First, in terms of technology as a firm specific asset, it is widely accepted that the US is the technological leader which gives the average US multinational a technological leadership vis-à-vis comparable UK companies. Foreign firms from other EU countries may, however, not have such a technological advantage compared with UK firms as they may be expected to have access to a fairly similar level of technology. On the other hand, considering industrial relations, we may expect less of a difference between US and UK firms, who have similar "Anglo-Saxon" industrial relations regimes, while firms from other continental EU countries (such as Germany and France) have very different labour market institutions (see, for example, Boeri et al., 2001). Hence, we may expect different effects from that point of view between EU and US firms.

In our data set we are able to distinguish three categories of nationalities, namely, US, EU and others. Table 5 presents a break-down of foreign acquisition by nationality of ownership. Overall, slightly more acquisitions were carried out by US multinationals than by firms from the two other nationality categories over the time period analysed.

\section{[Table 5 here]}

Table 6 reports the results of estimating the simultaneous wage equations defining $A C Q$ and $P A C Q$ for the three types of nationality groups (US, EU, others). Again we find 
substantial differences between the estimations for the whole and the matched sample, as in the previous estimations. Focusing our attention on the acquisition dummies shows that for skilled workers we only find a positive effect of takeovers by US multinationals here, wage rates are raised by an average of 5.9 and 10.9 percent post acquisition in the electronics and food industry, respectively. Recall that we did not find any statistically significant post acquisition effects in the food industry in the earlier estimations, which indicate the importance of allowing for the heterogeneity by home country of the foreign acquirer in the regressions.

Unskilled wages in the electronics industry are only positively affected if the acquirer was from another EU country or the rest of the world, while we do not find any effects post acquisition by an US firm. This is different for the food industry, where wages are raised post acquisition by US firms, but not by firms from other countries. These findings suggest that there is substantial heterogeneity in the post acquisition effects on wages of acquisitions by firms from different home countries. Hence, not taking account of this heterogeneity may miss out valuable information in the estimations and interpretations thereof.

[Table 6 here]

\section{Conclusions}

This paper investigates the effects of the takeover of a domestic establishment by foreign owners on the domestic target's development of average wages for skilled and unskilled workers. We pay particular attention to identifying the causal effect, using a propensity score matching approach combined with a difference-in-differences estimator, and differences in post acquisition effects depending on the nationality of the acquirer. 
Our results suggest that there is substantial heterogeneity in the post-acquisition wage effect depending on the nationality of the foreign acquirer, the industry in which the firms operate and the skill group of workers. In particular, we find that skilled workers, on average, experience a post acquisition increase in the wage rate following an acquisition by a US firm, while no such effect is discernable following acquisitions by EU or firms of other nationalities. For unskilled workers, there are positive post acquisition wage effects from take-overs by EU firms in the electronics industry and US firms in the food industry.

Overall, our results illustrate the substantial heterogeneity in the post acquisition effects. Hence, studies that do not account for heterogeneity in worker types, nationality of ownership and industry may be subject to considerable shortcomings. Also, our estimations point out the differences in results obtained when not controlling adequately for endogeneity and simultaneity bias.

One caveat of our analysis is that to the extent that there are positive (negative) wage spillovers from acquisition FDI to the control group of domestic establishments, the difference-in-differences procedure is likely to underestimate (overestimate) the causal effects of international takeovers on the wages of acquisition targets. One has probably to wait for a breakthrough in the theoretical econometrics literature before making a credible attempt at dealing with this potential source of bias. 


\section{References}

Barnes, M and Martin, R. (2002). 'Business data linking: An introduction', Economic Trends, No. 581, pp. 34-41.

Blundell, R. and Costa Dias, M. (2000). 'Evaluation methods for non-experimental data', Fiscal Studies, Vol. 21, pp. 427-468.

Boeri, T., Brugiavini, A. and Calmfors, L. (2001). The role of unions in the 21st century, Oxford University Press.

Brown, C. and Medoff, J. (1989). 'The employer size-wage effect'. Journal of Political Economy, Vol. 97, pp. 1027-1059.

Carmichael, F. (1992). 'Multinational enterprises and strikes: Theory and evidence', Scottish Journal of Political Economy, Vol. 39, pp. 52-68.

Caves, R.E. (1996). Economic Analysis of the Multinational Enterprise, Second edition, Cambridge University Press.

Conyon, M., Girma, S., Thompson, S and Wright, P. (2002).'The impact of foreign acquisition on wages and productivity in the U.K.', Journal of Industrial Economics, Vol. L, pp. 85-102.

Driffield, N. and Girma, S. (2003). 'Regional FDI and wages spillovers: Evidence from the UK Electronics Industry', Oxford Bulletin of Economics and Statistics, Vol. 65, pp. 453-474

Dunning, J.H. and Morgan, E. (1980). 'Employee Compensation in U.S. Multinationals and Indigenous Firms: An Exploratory Micro/Macro Analysis', British Journal of Industrial Relations, Vol. 18, pp. 179-201

Feliciano, Z. and Lipsey, R.E. (1999). 'Foreign ownership and wages in the United States, 1987 - 1992’ NBER Working Paper 6923.

Girma, S., Greenaway, D. and Wakelin, K. (2001). 'Who benefits from Foreign Direct Investment in the UK?', Scottish Journal of Political Economy, Vol. 48, pp. 119133

Girma, S. and Görg, H. (2002). 'Foreign ownership, returns to scale and productivity: Evidence from UK manufacturing establishments', CEPR Discussion Paper 3505.

Görg, H., Strobl E. and Walsh, F. (2002). 'Why do foreign firms pay more? The role of on-the-job training', IZA Discussion Paper 590, Bonn.

Griffith, R. and Simpson, H. (2003). 'Characteristics of foreign -owned firs in British manufacturing', in Blundell, R., D. Card and R. Freeman (eds), Creating a Premier League Economy, Chicago University Press.

Harris, R. and Robinson, C. (2002). 'The effect of foreign acquisitions on total factor productivity: Plant-level evidence from U.K manufacturing, 1987-1992', Review of Economics and Statistics, Vol. 84, pp. 562-568.

Heckman, J., Ichimura, H., Smith, J. and Todd, P. (1997). 'Matching as an Econometric Evaluation Estimator: Evidence from Evaluating a Job Training Programme', Review of Economic Studies, Vol. 64, pp.605-654.

Lipsey, R.E. and Sjöholm, F. (2001). 'Foreign direct investment and wages in Indonesian manufacturing', NBER Working Paper 8299.

Lipsey, R.E. and Sjöholm, F. (2002). 'Foreign firms and Indonesian manufacturing wages: An analysis with panel data', NBER Working Paper 9417.

Machin, S. and Van Reenen, J. (1998). 'Technology and changes in skill structure: evidence from seven OECD countries', Quarterly Journal of Economics, Vol. 113, pp. 1215-1244.

Markusen, J.R. (1995). 'The boundaries of Multinational Enterprises and the Theory of International Trade', Journal of Economic Perspectives, Vol. 9, pp.169-189. 
Nickell, S. and Wadhwani, S. (1990). 'Insider forces and wage determination', Economic Journal, Vol. 100, 496-509.

Rosenbaum, P. and Rubin, D.B (1983). 'The central role of the propensity score in observational studies for causal effects', Biometrika, Vol. 70, pp.41-55.

Sianesi, Barbara (2001). 'Implementing propensity score matching estimators with Stata', program available at http://fmwww.bc.edu/RePEc/usug2001/psmatch.pdf

Tybout, J. (2000). 'Manufacturing firms in developing countries: How well do they do, and why?', Journal of Economic Literature, Vol. 38, pp. 11-44. 
Table 1: Determinants of foreign acquisitions

\begin{tabular}{|l|l|l|}
\hline & Electronics & Food \\
\hline Skilled wages & 0.263 & 0.301 \\
\hline & $(2.26)^{* *}$ & $(2.21)^{* *}$ \\
\hline Unskilled wage & -0.085 & 0.397 \\
\hline & $(0.82)$ & $(2.37)^{* *}$ \\
\hline Assisted areas dummy & 0.029 & 0.058 \\
\hline & $(0.43)$ & $(0.64)$ \\
\hline Age & -0.071 & -0.009 \\
\hline & $(3.32)^{* * *}$ & $(0.19)$ \\
\hline Age squared & 0.003 & 0.000 \\
\hline & $(3.55)^{* * *}$ & $(0.16)$ \\
\hline Size & 1.097 & -0.120 \\
\hline & $(2.51)^{* *}$ & $(0.23)$ \\
\hline Size squared & -0.032 & 0.005 \\
\hline & $(2.30)^{* *}$ & $(0.31)$ \\
\hline Productivity growth & 9.132 & 12.292 \\
\hline & $(1.18)$ & $(1.85)^{*}$ \\
\hline Constant & -13.602 & -7.559 \\
\hline & $(3.64)^{* * *}$ & $(1.60)$ \\
\hline Observations & 9270 & 11067 \\
\hline
\end{tabular}

Notes:

(a) Absolute value of z-statistics in parentheses

(b) $\quad *$ significant at $10 \%$; * significant at $5 \% ; * * *$ significant at $1 \%$

(c) The source of this and all other statistical tables in this paper is ONS.

Table 2: Numbers of acquisitions and control group establishments

\begin{tabular}{|r|r|r|r|r|r|r|r|r|}
\hline & \multicolumn{2}{l}{ Electronics } & \multicolumn{4}{l|}{ Food } \\
\hline & \multicolumn{2}{|l|}{ Whole sample } & \multicolumn{2}{l|}{ Matched sample } & \multicolumn{3}{l|}{ Whole sample } & Matched sample \\
\hline & Control & Acquired & Control & Acquired & Control & Acquired & Control & Acquired \\
\hline 1981 & 893 & 8 & 168 & 8 & 1141 & $<=5$ & 105 & $<=5$ \\
\hline 1982 & 931 & 7 & 181 & 6 & 1146 & $<=5$ & 107 & $<=5$ \\
\hline 1983 & 926 & $<=5$ & 204 & $<=5$ & 1098 & 8 & 107 & 6 \\
\hline 1984 & 1214 & 23 & 207 & 20 & 1519 & 11 & 105 & 8 \\
\hline 1985 & 993 & $<=5$ & 213 & $<=5$ & 1144 & $<=5$ & 104 & $<=5$ \\
\hline 1986 & 995 & $<=5$ & 234 & $<=5$ & 1105 & $<=5$ & 108 & $<=5$ \\
\hline 1987 & 1015 & 13 & 228 & 12 & 1051 & 9 & 102 & 8 \\
\hline 1988 & 1047 & 15 & 237 & 12 & 1085 & $<=5$ & 107 & $<=5$ \\
\hline 1989 & 1424 & 29 & 232 & 23 & 1422 & 17 & 95 & 15 \\
\hline 1990 & 1099 & 14 & 240 & 12 & 1108 & 8 & 100 & $<=5$ \\
\hline 1991 & 1052 & 39 & 220 & 32 & 1082 & 13 & 97 & 11 \\
\hline 1992 & 1072 & 30 & 209 & 23 & 1055 & 8 & 90 & $<=5$ \\
\hline 1993 & 1043 & 19 & 196 & 14 & 1087 & 11 & 81 & 10 \\
\hline 1994 & 897 & 16 & 194 & $<=5$ & 776 & 6 & 77 & $<=5$ \\
\hline Total & & 228 & & 177 & & 108 & & 85 \\
\hline
\end{tabular}


Note: Exact numbers are suppressed when the number of acquisitions is less than five, lest we violate the disclosure criteria set by the ONS. 
Table 3: Summary statistics of some variables of interest

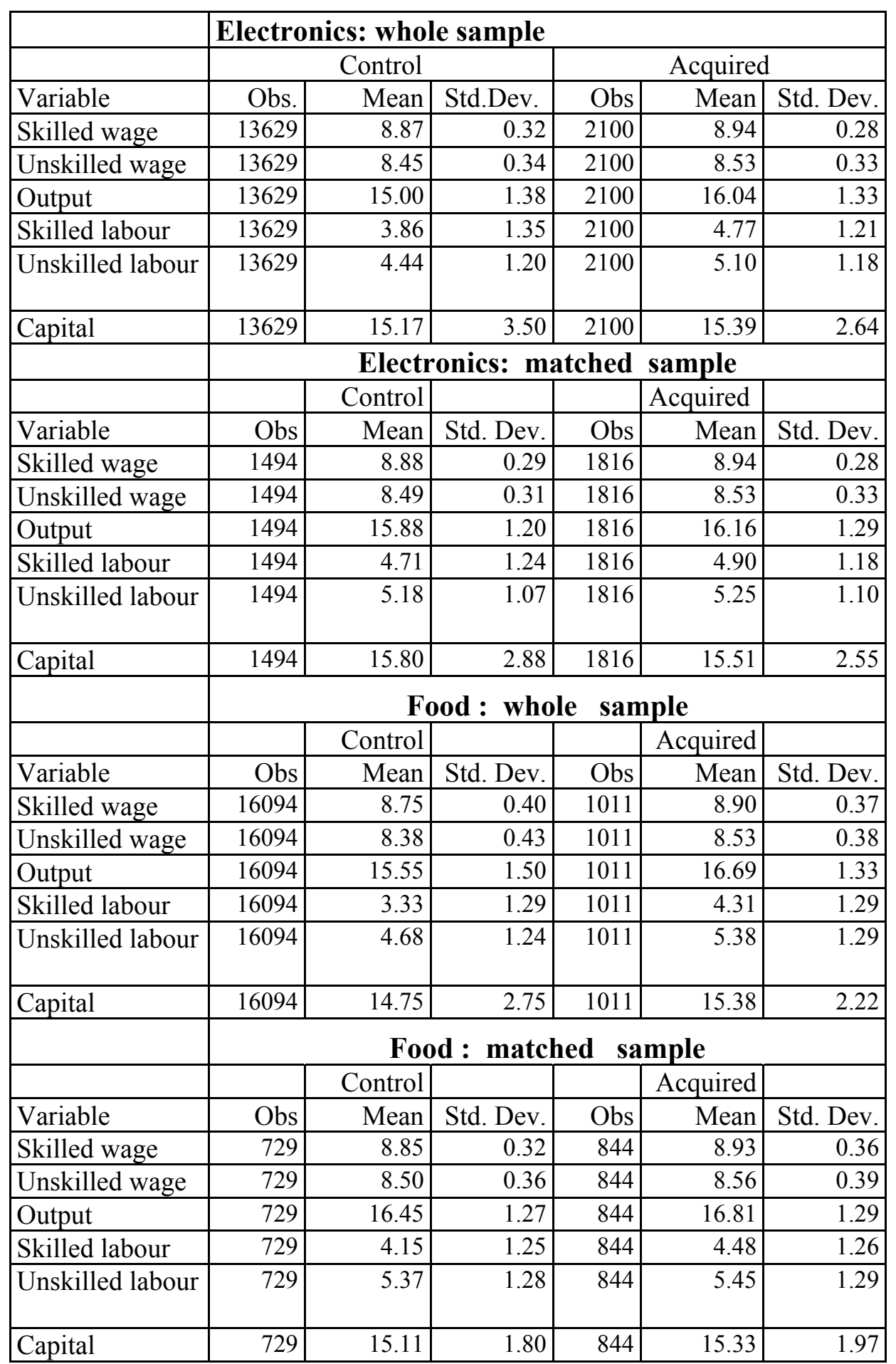

Note: All variables are in logarithm 
Table 4:

The effect of foreign acquisition on skilled and unskilled wages: Simultaneous equation estimates

\begin{tabular}{|c|c|c|c|c|}
\hline & \multicolumn{2}{|c|}{ Matched sample } & \multicolumn{2}{|l|}{ Whole sample } \\
\hline & Electronics & Food & Electronics & Food \\
\hline \multicolumn{5}{|l|}{ Skilled wage equation } \\
\hline \multirow[t]{2}{*}{ Unskilled wage } & -0.022 & 0.044 & 0.000 & 0.036 \\
\hline & $(0.76)$ & $(1.47)$ & $(0.01)$ & $(3.34)^{* * *}$ \\
\hline \multirow{2}{*}{$\begin{array}{l}\text { Regional and sectoral } \\
\text { skilled wage }\end{array}$} & 0.862 & 0.804 & 0.930 & 0.947 \\
\hline & $(22.51)^{* * *}$ & $(17.41)^{* * *}$ & $(47.49)^{* * *}$ & $(61.94)^{* * *}$ \\
\hline \multirow{2}{*}{ Capital } & 0.002 & 0.037 & 0.003 & 0.007 \\
\hline & $(1.44)$ & $(9.62)^{* * *}$ & $(4.40)^{* * *}$ & $(11.44)^{* * *}$ \\
\hline \multirow[t]{2}{*}{ Acquisition dummy } & 0.020 & 0.009 & 0.049 & 0.062 \\
\hline & $(1.09)$ & $(0.68)$ & $(2.63)^{* * *}$ & $(1.93)^{*}$ \\
\hline \multirow[t]{2}{*}{ Post acquisition dummy } & 0.024 & 0.030 & 0.066 & 0.069 \\
\hline & $(2.10) * *$ & $(1.47)$ & $(4.30)^{* * *}$ & $(3.90) * * *$ \\
\hline $\begin{array}{l}\text { Unskilled wage } \\
\text { equation }\end{array}$ & $(1.06)$ & $(0.78)$ & $(0.03)$ & $(0.75)$ \\
\hline \multirow[t]{2}{*}{ Skilled wage } & -0.097 & -0.132 & 0.097 & -0.029 \\
\hline & $(1.78)^{*}$ & $(2.31)^{* *}$ & $(4.27)^{* * *}$ & $(1.79)^{*}$ \\
\hline \multirow{2}{*}{$\begin{array}{l}\text { Regional and sectoral } \\
\text { unskilled wage }\end{array}$} & 0.958 & 0.999 & 0.871 & 1.026 \\
\hline & $(28.78)^{* * *}$ & $(33.22)^{* * *}$ & $(58.15)^{* * *}$ & $(90.28)^{* * *}$ \\
\hline \multirow[t]{2}{*}{ Capital } & 0.009 & 0.022 & 0.004 & 0.011 \\
\hline & $(5.06) * * *$ & $(5.69) * * *$ & $(6.48)^{* * *}$ & $(7.17)^{* * *}$ \\
\hline \multirow[t]{2}{*}{ Acquisition dummy } & 0.028 & 0.020 & 0.051 & 0.046 \\
\hline & $(1.23)$ & $(0.28)$ & $(2.77)^{* * *}$ & $(1.42)$ \\
\hline \multirow[t]{2}{*}{ Post acquisition dummy } & 0.040 & 0.003 & 0.046 & 0.077 \\
\hline & $(2.88) * * *$ & $(0.17)$ & $(5.71)^{* * *}$ & $(3.49)^{* * *}$ \\
\hline Observations & 3310 & 1573 & 16602 & 18531 \\
\hline
\end{tabular}

Notes:
(a) All regressions contain time dummies
(b) Absolute value of $\mathrm{z}$-statistics in parentheses
(c) $*$ significant at $10 \% ; * *$ significant at $5 \%$; *** significant at $1 \%$

Table 5: Number of acquisitions by home country of multinationals

\begin{tabular}{|c|c|c|c|c|}
\hline & \multicolumn{2}{|c|}{ Electronics } & \multicolumn{2}{c|}{ Food } \\
\hline & Whole sample & $\begin{array}{c}\text { Matched } \\
\text { sample }\end{array}$ & Whole sample & $\begin{array}{c}\text { Matched } \\
\text { sample }\end{array}$ \\
\hline EC countries & 74 & 56 & 38 & 29 \\
\hline USA & 85 & 63 & 38 & 31 \\
\hline Others & 69 & 58 & 32 & 25 \\
\hline Total & 228 & 177 & 108 & 89 \\
\hline
\end{tabular}


Table 6:

The effect of foreign acquisition on skilled and unskilled wages:

Is there a home country effect?

\begin{tabular}{|c|c|c|c|c|}
\hline & \multicolumn{2}{|c|}{ Matched sample } & \multicolumn{2}{|c|}{ Whole sample } \\
\hline & Electronics & Food & Electronics & Food \\
\hline \multicolumn{5}{|l|}{ Skilled wage equation } \\
\hline \multirow[t]{2}{*}{ Unskilled wage } & -0.018 & 0.050 & 0.001 & 0.036 \\
\hline & $(0.62)$ & $(1.64)^{*}$ & $(0.06)$ & $(3.34) * * *$ \\
\hline \multirow{2}{*}{$\begin{array}{l}\text { Regional and sectoral skilled } \\
\text { wage }\end{array}$} & 0.862 & 0.790 & 0.929 & 0.946 \\
\hline & $(22.54)^{* * *}$ & $(17.22)^{* * *}$ & $(47.44)^{* * *}$ & $(61.91)^{* * *}$ \\
\hline \multirow{2}{*}{ Capital } & 0.002 & 0.037 & 0.004 & 0.007 \\
\hline & $(1.46)$ & $(9.46) * * *$ & $(4.41)^{* * *}$ & $(11.43)^{* * *}$ \\
\hline \multirow[t]{2}{*}{ EC acquisition dummy } & -0.002 & 0.057 & 0.061 & 0.038 \\
\hline & $(0.05)$ & $(1.11)$ & $(1.13)$ & $(1.88)^{*}$ \\
\hline \multirow[t]{2}{*}{ EC post acquisition dummy } & 0.025 & -0.006 & 0.043 & 0.036 \\
\hline & $(1.24)$ & $(0.51)$ & $(4.37)^{* * *}$ & $(0.96)$ \\
\hline \multirow{2}{*}{ USA acquisition dummy } & 0.023 & 0.057 & 0.014 & -0.022 \\
\hline & $(0.76)$ & $(0.41)$ & $(1.89)^{*}$ & $(1.70)^{*}$ \\
\hline \multirow[t]{2}{*}{ USA post acquisition dummy } & 0.059 & 0.109 & 0.078 & 0.152 \\
\hline & $(3.57)^{* * *}$ & $(1.99)^{* *}$ & $(1.03)$ & $(4.82) * * *$ \\
\hline \multirow{2}{*}{ OTHERS acquisition dummy } & 0.038 & -0.014 & 0.058 & 0.059 \\
\hline & $(1.20)$ & $(0.25)$ & $(2.47)^{* *}$ & $(1.00)$ \\
\hline \multirow{2}{*}{$\begin{array}{l}\text { OTHERS post acquisition } \\
\text { dummy }\end{array}$} & -0.019 & -0.058 & 0.104 & 0.047 \\
\hline & $(1.03)$ & $(1.47)$ & $(5.19)^{* * *}$ & $(1.46)$ \\
\hline \multicolumn{5}{|l|}{ Unskilled wage equation } \\
\hline \multirow[t]{2}{*}{ Skilled wage } & -0.094 & -0.142 & 0.098 & -0.030 \\
\hline & $(1.73)^{*}$ & $(2.45)^{* *}$ & $(4.33) * * *$ & $(1.82)^{*}$ \\
\hline \multirow{2}{*}{$\begin{array}{l}\text { Regional and sectoral unskilled } \\
\text { wage }\end{array}$} & 0.953 & 1.002 & 0.870 & 1.026 \\
\hline & $(28.62)^{* * *}$ & $(33.05)^{* * *}$ & $(58.07)^{* * *}$ & $(90.28)^{* * *}$ \\
\hline \multirow[t]{2}{*}{ Capital } & 0.009 & 0.022 & 0.003 & 0.011 \\
\hline & $(5.07) * * *$ & $(5.64)^{* * *}$ & $(6.47)^{* * *}$ & $(7.16)^{* * *}$ \\
\hline \multirow[t]{2}{*}{ EC acquisition dummy } & 0.011 & -0.017 & 0.035 & 0.102 \\
\hline & $(0.29)$ & $(0.34)$ & $(1.79)^{*}$ & $(0.70)$ \\
\hline \multirow[t]{2}{*}{ EC post acquisition dummy } & 0.066 & -0.017 & 0.094 & 0.013 \\
\hline & $(2.81)^{* * *}$ & $(0.19)$ & $(2.21)^{* *}$ & $(0.36)$ \\
\hline \multirow[t]{2}{*}{ USA acquisition dummy } & 0.001 & -0.020 & 0.054 & 0.092 \\
\hline & $(0.03)$ & $(1.22)$ & $(0.45)$ & $(0.40)$ \\
\hline \multirow[t]{2}{*}{ USA post acquisition dummy } & -0.001 & 0.057 & 0.018 & 0.112 \\
\hline & $(0.07)$ & $(3.83)^{* * *}$ & $(4.82)^{* * *}$ & $(3.53)^{* * *}$ \\
\hline \multirow[t]{2}{*}{ OTHERS acquisition dummy } & 0.073 & 0.013 & 0.087 & 0.056 \\
\hline & $(1.93)^{*}$ & $(0.26)$ & $(1.81)^{*}$ & $(0.94)$ \\
\hline \multirow{2}{*}{$\begin{array}{l}\text { OTHERS post acquisition } \\
\text { dummy }\end{array}$} & 0.070 & -0.049 & 0.006 & 0.045 \\
\hline & $(3.26)^{* * *}$ & $(1.79)^{*}$ & $(0.32)$ & $(1.37)$ \\
\hline Observations & 3310 & 1573 & 16602 & 18531 \\
\hline
\end{tabular}

Notes: see Table 4 


\section{IZA Discussion Papers}

\begin{tabular}{|c|c|c|c|c|}
\hline No. & Author(s) & Title & Area & Date \\
\hline 889 & D. E. Wildasin & $\begin{array}{l}\text { Fiscal Policy, Human Capital, and Canada-US } \\
\text { Labor Market Integration }\end{array}$ & 2 & $10 / 03$ \\
\hline 890 & $\begin{array}{l}\text { M. Bratti } \\
\text { L. Mancini }\end{array}$ & $\begin{array}{l}\text { Differences in Early Occupational Earnings of } \\
\text { UK Male Graduates by Degree Subject: } \\
\text { Evidence from the 1980-1993 USR }\end{array}$ & 6 & $10 / 03$ \\
\hline 891 & $\begin{array}{l}\text { L. Flood } \\
\text { E. Pylkkänen } \\
\text { R. Wahlberg }\end{array}$ & $\begin{array}{l}\text { From Welfare to Work: Evaluating a Proposed } \\
\text { Tax and Benefit Reform Targeted at Single } \\
\text { Mothers in Sweden }\end{array}$ & 6 & $10 / 03$ \\
\hline 892 & B. T. Hirsch & What Do Unions Do for Economic Performance? & 5 & $10 / 03$ \\
\hline 893 & K. Sabirianova Peter & $\begin{array}{l}\text { Skill-Biased Transition: The Role of Markets, } \\
\text { Institutions, and Technological Change }\end{array}$ & 4 & $10 / 03$ \\
\hline 894 & R. Winkelmann & Parental Separation and Well-Being of Youths & 7 & $10 / 03$ \\
\hline 895 & $\begin{array}{l}\text { J. M. Fitzgerald } \\
\text { D. C. Ribar }\end{array}$ & $\begin{array}{l}\text { Transitions in Welfare Participation and Female } \\
\text { Headship }\end{array}$ & 3 & $10 / 03$ \\
\hline 896 & S. W. Polachek & $\begin{array}{l}\text { What Can We Learn About the Decline in U.S. } \\
\text { Union Membership from International Data? }\end{array}$ & 2 & $10 / 03$ \\
\hline 897 & $\begin{array}{l}\text { M. Brown } \\
\text { A. Falk } \\
\text { E. Fehr }\end{array}$ & $\begin{array}{l}\text { Relational Contracts and the Nature of Market } \\
\text { Interactions }\end{array}$ & 7 & $10 / 03$ \\
\hline 898 & $\begin{array}{l}\text { G. J. van den Berg } \\
\text { A. G. C. van Lomwel } \\
\text { J. C. van Ours }\end{array}$ & $\begin{array}{l}\text { Nonparametric Estimation of a Dependent } \\
\text { Competing Risks Model for Unemployment } \\
\text { Durations }\end{array}$ & 1 & $10 / 03$ \\
\hline 899 & $\begin{array}{l}\text { M. Karanassou } \\
\text { H. Sala } \\
\text { D. J. Snower }\end{array}$ & $\begin{array}{l}\text { Unemployment in the European Union: } \\
\text { Institutions, Prices, and Growth }\end{array}$ & 2 & $10 / 03$ \\
\hline 900 & $\begin{array}{l}\text { M. C. Berger } \\
\text { G. C. Blomquist } \\
\text { K. Sabirianova Peter }\end{array}$ & $\begin{array}{l}\text { Compensating Differentials in Emerging Labor } \\
\text { and Housing Markets: Estimates of Quality of } \\
\text { Life in Russian Cities }\end{array}$ & 4 & $10 / 03$ \\
\hline 901 & $\begin{array}{l}\text { P. F. Orazem } \\
\text { M. Vodopivec }\end{array}$ & $\begin{array}{l}\text { Do Market Pressures Induce Economic } \\
\text { Efficiency: The Case of Slovenian } \\
\text { Manufacturing, 1994-2001 }\end{array}$ & 4 & $10 / 03$ \\
\hline 902 & $\begin{array}{l}\text { P. Frijters } \\
\text { M. A. Shields } \\
\text { S. Wheatley Price }\end{array}$ & $\begin{array}{l}\text { Immigrant Job Search in the UK: Evidence from } \\
\text { Panel Data }\end{array}$ & 1 & $10 / 03$ \\
\hline 903 & $\begin{array}{l}\text { S. Girma } \\
\text { H. Görg }\end{array}$ & $\begin{array}{l}\text { Evaluating the Causal Effects of Foreign } \\
\text { Acquisition on Domestic Skilled and Unskilled } \\
\text { Wages }\end{array}$ & 2 & $10 / 03$ \\
\hline
\end{tabular}

An updated list of IZA Discussion Papers is available on the center's homepage www.iza.org. 